Article

\title{
Antimicrobial Activity of Microorganisms Isolated from Ant Nests of Lasius niger
}

\author{
Tatiana A. Efimenko ${ }^{1, * \mathbb{D}}$, Alla A. Glukhova ${ }^{1}$, Mariia V. Demiankova ${ }^{1}$, Yuliya V. Boykova ${ }^{1}$, \\ Natalia D. Malkina ${ }^{1}$, Irina G. Sumarukova ${ }^{1}$, Byazilya F. Vasilieva ${ }^{1}$, Eugene A. Rogozhin ${ }^{1,2}{ }^{\circledR}$, \\ Igor A. Ivanov ${ }^{2}$, Vladislav A. Krassilnikov ${ }^{3}$ and Olga V. Efremenkova ${ }^{1}$ (D) \\ 1 Gause Institute of New Antibiotics, 119021 Moscow, Russia; alglukhova@yandex.ru (A.A.G.); \\ mary_bunny@mail.ru (M.V.D.); alexseybaa92@yandex.ru (Y.V.B.); utvar@blagoslovenie.su (N.D.M.); \\ noks59@yandex.ru (I.G.S.); bfvas@yandex.ru (B.F.V.); rea21@list.ru (E.A.R.); ovefr@yandex.ru (O.V.E.) \\ 2 Shemyakin-Ovchinnikov Institute of Bioorganic Chemistry of the Russian Academy of Sciences, \\ 117997 Moscow, Russia; chai.mail0@gmail.com \\ 3 Russian Entomological Society, 199034 Saint-Petersburg, Russia; lasius@yandex.ru \\ * Correspondence: efimen@inbox.ru
}

Received: 5 June 2020; Accepted: 20 June 2020; Published: 22 June 2020

\begin{abstract}
In this study, the microbial communities of two nests of black garden ants (Lasius niger) in the hollows of stem branches of old apple trees were found to have similar species compositions: each community contained representatives of three species from the Bacillaceae family and one species of actinomycetes from the genus Streptomyces. In total, four types of bacilli and two actinomycetes were isolated. Actinomycetes were identified as Streptomyces antibioticus-like and Streptomyces sp. None of the bacilli had antibiotic activity, whereas both streptomycetes produced antibiotics that inhibited the growth of Gram-positive bacteria in vitro, including isolates from their community. Antibiotic compounds of S. antibioticus-like strain INA 01148 (Institute of New Antibiotics) were identified as actinomycin D and its closest homologue, actinomycin A. Actinomycins presumably change the microbial community of the ant nest substrate as they act against Gram-positive bacteria and against fungi and Gram-negative bacteria. The antibiotic activity of the isolated Streptomyces sp. INA 01156 is of interest, since the substances produced by this strain inhibit the growth of drug-resistant bacteria, including methicillin-resistant Staphylococcus aureus INA 00761 (MRSA) and vancomycin-resistant strain Leuconostoc mesenteroides VKPM B-4177 (VR) (VKPM-National Collection of Industrial Microorganisms (Russian acronym)).
\end{abstract}

Keywords: ant nests; Lasius niger; microbial community; actinomycetes; bacilli; Streptomyces antibioticus-like; actinomycin D

\section{Introduction}

The study of natural microbial communities is of both general theoretical and descriptive interest and has significant application potential as microorganisms produce a large number of substances of value. In particular, most modern antibiotics are produced by microorganisms, but due to the increasing problem of resistance of pathogens to antibiotics, the search for new effective drugs must be continuous. To search for producers of new natural antibiotics, microorganisms can be isolated from insufficiently studied sources, for example, from bottom sediments of seas and freshwater ponds, from frozen soils, and from the symbionts of plants and animals-in this case, from ants and their habitats [1-3].

Ants are complexly organized social animals that are widespread across all continents (except Antarctica), living in many different conditions with different food resources. More than 14,000 species 
of ants have been described, and living species together account for as much as $10-25 \%$ of the biomass of all terrestrial animals [4]. However, only some species of ants have been studied for microorganisms on their integument, inside them, or in their nests. Most of the studies in this area have focused on leaf-cutting ants from the genera Atta and Acromyrmex, which live in the Western Hemisphere. These ants are also called fungus-growing ants, because they arrange fungi gardens for food in their nests, in which basidiomycetes from the family Agaricaceae are cultivated on shredded leaves. The productivity of such fungi decreases if the ascomycete fungi Escovopsis spp., which parasitize the fungi cultivated by the ants, settle in the nest. The success of these fungi is facilitated by the actinomycetes Pseudonocardia spp., which have been repeatedly found in ant nests. Representatives of the genus Pseudonocardia produce antibiotics that inhibit the growth of Escovopsis spp. [5-10].

The structure of one of the antibiotics produced by Pseudonocardia sp. associated with the fungus-growing ants Apterostigma dentigerum has been established. It is a dentigerumycin which is a cyclic depsipeptide with highly modified amino acids that selectively inhibits the associated parasitic fungus (Escovopsis spp.) [11,12]. The structures of the antibiotics gerumycins A-C produced by two different symbiotic Pseudonocardia spp. from ant nests are slightly smaller versions of dentigerumycin [13]. In addition to Pseudonocardia spp., symbionts of ants of other genera of actinomycetes have been isolated: Amycolatopsis, Kitassatospora, Kribbella, Propionicimonas, Streptomyces, and Tsukamurella [7,14-17]. Known antibiotic antimycins A1-A4, valinomycins, and actinomycins, as well as macrolide antibiotic candicidins, have been identified from Streptomyces symbionts of leaf-cutting ants $[18,19]$. The authors of these publications suggested that actinomycetes impact the protection of ants or sanitation of the nest due to the formation of antibiotics.

Another series of publications deals with microorganisms associated with black garden ants (Lasius niger), which are widely distributed in Eurasia [20,21]. These ants feed on small invertebrates, as well as the sweet secretions of the aphids that they cultivate and protect [22]. In their anthills, representatives of the genus Bacillus dominate, and bacteria of other taxonomic groups, as well as actinomycetes of the genus Streptomyces, which, under laboratory conditions, exhibit antibiotic properties against bacteria from the same anthill, have also been found [23]. A comparative analysis of the abundance and biodiversity of actinomycete communities isolated from the living ants L. niger and Formica cunicularia, as well as their anthills, showed that the number of actinomycetes detected in L. niger ants is close to the number of actinomycetes in their anthills and the higher than that for F. cunicularia. The main actinomycetes were representatives of the genus Streptomyces, but Micromonospora and Nocardia were also found. The biodiversity of actinomycetes associated with living ants is considerably lower than in their nests and the surrounding soil [24,25].

The objectives of our study were to assess the diversity of microorganisms present in the nests of black garden ants (L. niger) and to explore their antibiotic properties.

\section{Materials and Methods}

\subsection{Sampling of Substrates from the Ant Nests and Isolation of Microorganisms}

The ant nests were located in the cavities of stem branches of two old apple trees in the Moscow Region, Russia. The trees were growing in a garden at a distance of $5 \mathrm{~m}$ from each other. The cavities were filled with a substrate resembling coarse-grained soil. Samples of the substrate were taken at the end of May 2016 in dry hot weather by hand using a sterile glove and placed in a sterile paper bag. Portions of $0.2 \mathrm{~g}$ of the substrates were added into $5 \mathrm{~mL}$ of sterile water, stirred in a shaker for $10 \mathrm{~min}$, filtered through cotton, diluted, and plated on an agar medium within one week. After incubation at a temperature of $28^{\circ} \mathrm{C}$ for 7 days, colonies of different types were seeded into tubes with a slanted agar medium. The reseeded clones were incubated for 1-4 days (bacteria) and 10-12 days (actinomycetes). 


\section{2. $p H$ Determination of Substrates from the Ant Nests}

To the weighed substrate, we added distilled water at a ratio of $1: 5$ before shaking for $1 \mathrm{~h}$, filtered, and determined $\mathrm{pH}$ using a $\mathrm{pH}$ tester.

\subsection{Media and Culture Conditions}

For storage and maintenance of all microorganisms, modified agar Gause medium \#2 was used (\%): glucose 1, peptone 0.5 , tryptone $0.3, \mathrm{NaCl} 0.5$, agar 2, and tap water (pH 7.2-7.4). The same medium without agar was used for the bacterial submerged cultivation and for the first stage of actinomycete cultivation. Liquid media for the second stage of actinomycete submerged cultivation were developed for strains producing antibiotics at the Gause Institute of New Antibiotics as described previously [26]. The composition of these media is indicated in \%:

A (2663): glycerin 3, soy flour $1.5, \mathrm{NaCl} 0.3$, chalk 0.3 , tap water ( $\mathrm{pH} 7.0$ );

B (A4): glucose 1 , soy flour $1, \mathrm{NaCl} 0.5$, chalk 0.25 , tap water ( $\mathrm{pH} 6.8$ );

$\mathrm{C}$ (Suc): sucrose 2 , soy flour $1, \mathrm{NaCl} 0.3$, chalk 0.3 , tap water ( $\mathrm{pH} 6.8-7.0$ );

$\mathrm{D}$ (5339): glycerin 2 , soy flour $0.5,\left(\mathrm{NH}_{4}\right)_{2} \mathrm{SO}_{4} 0.15, \mathrm{NaCl} 0.3$, chalk 0.3 , tap water ( $\mathrm{pH} 6.8$ );

$\mathrm{E}$ (6613): starch 2, corn extract $0.3, \mathrm{KNO}_{3} 0.4, \mathrm{NaCl} 0.5$, chalk 0.5 , tap water (pH 7.0-7.2);

$\mathrm{F}$ (330): sucrose 2.1, starch 0.85 , pea flour 1.5, $\mathrm{NaCl} 0.5, \mathrm{NaNO}_{3} 0.5$, chalk 0.5 , tap water (pH 7.0);

$\mathrm{G}(\mathrm{Am})$ : sucrose 4, yeast extract $0.25, \mathrm{~K}_{2} \mathrm{HPO}_{4} 0.1, \mathrm{Na}_{2} \mathrm{SO}_{4} 0.1, \mathrm{NaCl} 0.1,\left(\mathrm{NH}_{4}\right)_{2} \mathrm{SO}_{4} 0.2$, $\mathrm{FeSO}_{4} \cdot 7 \mathrm{H}_{2} \mathrm{O} 0.0001, \mathrm{MnCl}_{2} \cdot 4 \mathrm{H}_{2} \mathrm{O} 0.0001$, NaI 0.00005, chalk 0.2, distilled water ( $\mathrm{pH}$ 6.5-6.7).

Submerged cultivation was carried out in $750 \mathrm{~mL}$ Erlenmeyer flasks with $150 \mathrm{~mL}$ of medium on a rotary shaker at $200 \mathrm{rpm}$ at $28^{\circ} \mathrm{C}$. Inoculation with bacteria was conducted with a suspension of $10^{7}$ cells $/ \mathrm{mL}$ of medium and antimicrobial activity in the culture liquid was determined after $1,2,4$, and 7 days of growth. Actinomycetes in the first stage of cultivation were inoculated with a piece of agar medium into flasks with mycelium. After four days of growth, $7.5 \mathrm{~mL}$ of the culture grown in the first stage was transferred to flasks $(1.5 \% \mathrm{v} / \mathrm{v})$. The second stage of cultivation lasted 4-7 days. Bacterial test strains on the agar medium were grown at $37{ }^{\circ} \mathrm{C}$ with the exception of Leuconostoc mesenteroides VKPM B-4177 which was grown at $28^{\circ} \mathrm{C}$. Fungal test strains Aspergillus niger INA 00760 and Saccharomyces cerevisiae INA 01129 were grown at $28^{\circ} \mathrm{C}$ for 48 and 24 h, respectively.

\subsection{Species Identification of Bacteria}

\subsubsection{Morphological Characteristics}

Bacteria were cultured on Gause medium \#2. For the description of the actinomycetes' cultural and morphological characteristics, Gause media \#1, glycerin-nitrate agar and media ISP3, ISP4, and ISP5 were additionally used $[27,28]$. To describe the bacteria, the morphology of cells and spores was examined using a Micmed-6 light microscope (LOMO, Saint-Petersburg, Russia). For actinomycete species identification, characteristics such as the structure of the sporophores, the spore surface, the pigmentation of the air mycelium and substrate mycelium, and the pigment released into the medium were considered. Actinomycete spores were studied using a JEOL-6060A scanning electron microscope (JEOL, Tokyo, Japan) with a tungsten cathode. Before the study, platinum was sprayed onto the samples using a JFC-1600 apparatus (JEOL, Tokyo, Japan).

\subsubsection{Molecular Characteristics}

The species of the isolated bacteria were determined via identification of the 16S rRNA gene sequences. Genomic DNA from the bacterial biomass was isolated using the PowerSoil DNA Kit (MO BIO, Carlsbad, CA, USA). PCR of the $16 \mathrm{~S}$ rRNA gene was performed using a set of PCR Master Mix reagents (contains the Taq DNA polymerase; Thermo Scientific, Foster City, CA, USA) with universal bacterial primers: 27F (AGA GTT TGA TCC TGG CTCAG) and 1492R (TAC GGY TAC CTT GTT ACG ACT T) [29]. PCR was performed on a Thermal Cycler 2720 device (Applied Biosystems, Foster City, USA) according to the following program: (1) $94{ }^{\circ} \mathrm{C}$ for $5 \mathrm{~min}$; (2) 30 cycles with temperature 
intervals of $94{ }^{\circ} \mathrm{C}$ for $1 \mathrm{~min}, 51^{\circ} \mathrm{C}$ for $1 \mathrm{~min}$, and $72{ }^{\circ} \mathrm{C}$ for $2 \mathrm{~min}$; (3) $72{ }^{\circ} \mathrm{C}$ for $7 \mathrm{~min}$. The nucleotide sequences were determined using the Sanger method on a Genetic Analyzer 3500 automatic sequencer (Applied Biosystems, Beverly, MA, USA) using universal bacterial primers: 27f, 341f (CCT ACG GGA GGC AGC AG), 1100r (GGG TTG CGC TCG TTG), and 1492r. The obtained sequences were aligned with the nucleotide sequences of the 16S rRNA gene of the bacterial type strains from the GenBank databases (blast.ncbi.nlm.nih.gov/Blast.cgi) and the Ribosomal Database Project (rdp.cme.msu.edu/) using the ClustalW program included in the MEGA7 program [30]. To construct phylogenetic trees, the neighbor-joining method was used, which is also included in the MEGA7 program. The statistical confidence of the branching order was established using bootstrap analysis of 10,000 alternative trees.

\subsection{Determination of Antimicrobial Activity}

To determine the antibiotic activity of microorganisms isolated from the ant nests, the following test strains were used: Bacillus subtilis ATCC 6633, Bacillus mycoides 537, Bacillus pumilus NCTC 8241, Leuconostoc mesenteroides VKPM B-4177 (a vancomycin-resistant strain, VR), Micrococcus luteus NCTC 8340, Staphylococcus aureus FDA 209P (methicillin-susceptible Staphylococcus aureus, MSSA), St. aureus INA 00761 (methicillin-resistant Staphylococcus aureus, MRSA), Mycobacterium smegmatis VKPM Ac 1339, Mycobacterium smegmatis mc ${ }^{2}$ 155, Escherichia coli ATCC 25922, Comamonas terrigena ATCC 8461, Pseudomonas aeruginosa ATCC 27853, Aspergillus niger INA 00760, and Saccharomyces cerevisiae INA 01129. Antibiotic activity was determined using the diffusion agar method. For this purpose, $100 \mu \mathrm{L}$ aliquots of the tested solution were added to $9 \mathrm{~mm}$ diameter holes in the agar medium inoculated with the test strains. After incubation of 20-24 h, the diameters of the growth-inhibitory zones of the test strains were measured as an indicator of antibiotic action.

\subsection{Isolation and Identification of Antibiotics}

The supernatant of the Streptomyces antibioticus-like INA 01148 culture liquid was separated by centrifugation from the mycelium. Wet mycelia were extracted with ethanol at a neutral $\mathrm{pH}$ value. The supernatant was applied to Amberlyte XAD-2 (Serva Electrophoresis GMBH, Heidelberg, Germany) following elution by a mixture of $\mathrm{n}$-butanol/acetone/water (1:1:1) at a neutral $\mathrm{pH}$ value. The eluate and the extract were dried at $37^{\circ} \mathrm{C}$ and the residue was dissolved in methanol. The ratio of methanol concentrates to the volume of the original culture liquid was 1:100. The concentrates were analyzed by ultraviolet-visible (UV-Vis) spectrophotometry and thin-layer chromatography (TLC) on $10 \times 10 \mathrm{~cm}^{2}$ DC-Alufolien Kieselgel 60 (Merck, Darmstadt, Germany) plates in a chloroform/methanol/water system (95:5:1). Antibiotic activity was determined by bioautography using test strain St. aureus INA 00761 (MRSA). The concentrates were initially separated by reversed-phase high-performance liquid chromatography (RP-HPLC) on an XBridge Ethylene Bridged Hybrid (BEH) column (C18 $250 \times 4.6 \mathrm{~mm}^{2}, 5 \mu \mathrm{m}, 130 \AA$ ) (Waters Corporation, Milford, MA, USA). Each sample $(100 \mu \mathrm{L})$ was separated with a combined linear gradient of acetonitrile concentration from $16 \%$ to $95 \%$ solvent $\mathrm{B}$ ( $80 \% \mathrm{MeCN}$ with the addition of $0.1 \%$ trifluoroacetic acid) relative to solvent $\mathrm{A}(0.1 \%$ trifluoroacetic acid) for $60 \mathrm{~min}$. The flow rate was $950 \mu \mathrm{L} / \mathrm{min}$ and detection was monitored at $237 \mathrm{~nm}$.

The samples were analyzed by ultra-performance liquid chromatography/mass spectrometry (UPLC-MS) using a Thermo Finnigan LCQ Deca XP Plus ion trap instrument with a Thermo Accela UPLC system (Thermo Fisher Scientific, Waltham, MA, USA) equipped with a YMC Triart microcolumn $\left(\mathrm{C} 18150 \times 2 \mathrm{~mm}^{2}, 1.9 \mu \mathrm{m}\right)($ YMC Co., Kyoto, Japan). Absorbance detection was monitored by an ultraviolet-visible diode array detector (UV-VIS DAD) (190-600 nm) and full scan mass spectrometry (MS) (electro spray ionization (ESI+), 150-2000 au). The samples were dissolved in a mixture of water/methanol/acetic acid (88:10:2) to a final concentration of $1 \mathrm{mg} / \mathrm{mL}$, filtered through a $0.45 \mu \mathrm{m}$ nylon filter, and injected into the liquid chromatography (LC) system. 


\section{Results}

\subsection{Identification of Ants and Microorganisms from the Substrate of the Ant Nests}

Ant species were identified according to morphological characteristics (Figure 1) [20,21]. The black garden ant (Lasius niger (Linnaeus, 1758)) is the most common type of ant in Russia. Their colonies may be formed in small mounds, as well as under the bark and in the cavities of old trees, as in this case.

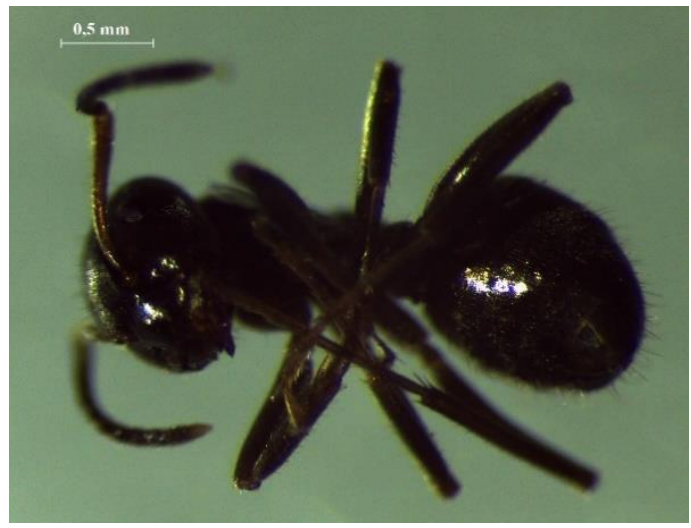

Figure 1. Black garden ant Lasius niger.

Gause agar medium \#2, which is optimal for the growth of most cultivated bacteria and fungi according to our experience, was used to seed a suspension of substrates from the ant nests. The titers of colony-forming units (CFU) in the substrates of two ant nests are shown in Table 1.

Table 1. General characteristics of two ant nests.

\begin{tabular}{ccccc}
\hline \multirow{2}{*}{ Ant Nests } & Apple Variety & \multicolumn{3}{c}{ Substrate in Ant Nests } \\
\cline { 3 - 5 } & & Color & pH & CFU/g * \\
\hline 1 & Antonovka & Brown & $7.81 \pm 0.08$ & $1.3 \times 10^{5}$ \\
2 & Korichnoe & Black & $7.22 \pm 0.13$ & $8.2 \times 10^{4}$ \\
\hline
\end{tabular}

${ }^{*}$ colony forming units/g (CFU).

Fungal colonies were completely absent in seeding. Four morphological types of bacterial colonies, including one type of actinomycete colonies, were found in each of the two substrates. About four to eight colonies of each type were removed into tubes with the agar medium. Three bacteria of each ant nest were Gram-positive, rod-shaped, and formed endospores, which indicated their belonging to the Bacillaceae family. Refinement of their taxonomic position and species identification were achieved using $16 \mathrm{~S}$ rRNA gene sequence analysis (Table 2). The phylogenetic trees of six bacilli are shown in Figure 2.

Table 2. Species identification of microorganisms from ant nests of Lasius niger by $16 \mathrm{~S}$ rRNA gene analysis.

\begin{tabular}{ccccc}
\hline Ant Nests & Species, Strains & DNA (bp) & Percent Identity & $\begin{array}{c}\text { Accession Numbers of the } \\
\text { Deposited Sequences (GenBank) }\end{array}$ \\
\hline \multirow{2}{*}{1} & Bacillus muralis-like INA 01162 & 1393 & 98 & MT023087 \\
Bacillus sp. INA 01161 & 1437 & 99.5 & MT023086 \\
& Lysinibacillus pakistanensis-like INA 01164 & 1403 & 100 & MT023089 \\
& Streptomyces antibioticus-like INA 01148 & 1299 & 100 & MT023090 \\
\hline \multirow{2}{*}{2} & Bacillus aryabhattai-like INA 01159 & 1405 & 99.5 & MT126414 \\
& Bacillus muralis-like INA 01160 & 1396 & 98.7 & MT126415 \\
& Bacillus sp. INA 01158 & 1431 & 100 & MT126413 \\
\end{tabular}




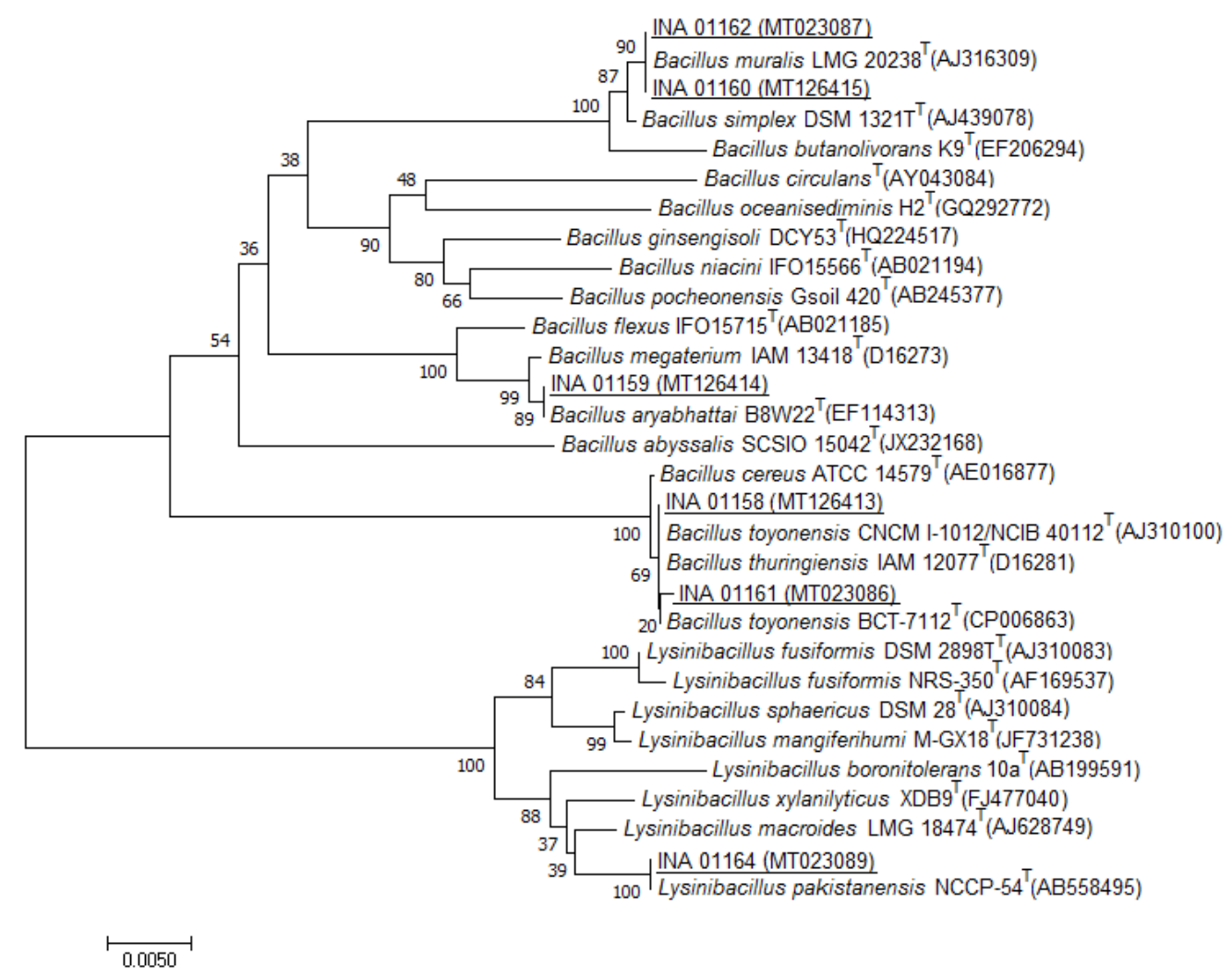

Figure 2. Phylogenetic position of the strains INA 01158-INA 01162 and INA 01164 based on the results of comparative analysis of the $16 \mathrm{~S}$ rRNA gene nucleotide sequences. The scale corresponds to five base substitutions for every 1000 nucleotides (evolutionary distance). INA-Institute of New Antibiotics, LMG-Collection of the Laboratorium voor Microbiologie en Microbiele Genetica, DSM-Deutsche Sammlung von Mikroorganismen und Zellkulturen, IAM-Institute of Applied Microbiology, SCSIO-South China Sea Institute of Oceanology, ATCC-American Type Culture Collection, and CNCM-Collection Nationale de Cultures de Microorganismes.

Actinomycetes were identified by morphological characteristics and the 16S rRNA gene. Four actinomycete clones of nest 1 were slightly different from each other in terms of the color of the aerial mycelium (white, light gray, or gray), folding, and the diameter of the colonies. However, these differences were not fundamental, and these actinomycete isolates were characterized by common features such as short straight spore chains, smooth spore surface, gray aerial mycelium, substrate mycelium, and soluble pigment of yellow color when grown on Gause mineral agar medium \#1 and of brown color on Gause agar medium \#2. According to these characteristics, the species was identified as Streptomyces antibioticus-like. The sequences of the 16S rRNA gene of this actinomycete showed $100 \%$ similarity to the type strain S. antibioticus NRRL B-1701 (NRRL-Northen Regional Research Center) (Table 2, Figure 3). One of the actinomycete isolates was deposited in the culture collection of the Gause Institute of New Antibiotics (Russia) as S. antibioticus-like INA 01148.

Four actinomycete clones from nest 2 were characterized by a well-formed white aerial mycelium on Gause agar medium \#2 or a white aerial mycelium with a light gray tint on Gause mineral agar medium $\# 1$, as well as colorless substrate mycelium; soluble pigment was not produced. This actinomycete had convoluted sporogenous hyphae and spores with characteristic spiky outgrowths (Figure 4). This description most closely matched the description of Streptomyces cyanoalbus, although the coincidence with the type strain of this species in the database was only $90.7 \%$ (Table 2, Figure 5) [31,32]. One actinomycete isolate was deposited in the collection as Streptomyces sp. INA 01156, and the study of its taxonomic affiliation will continue. 


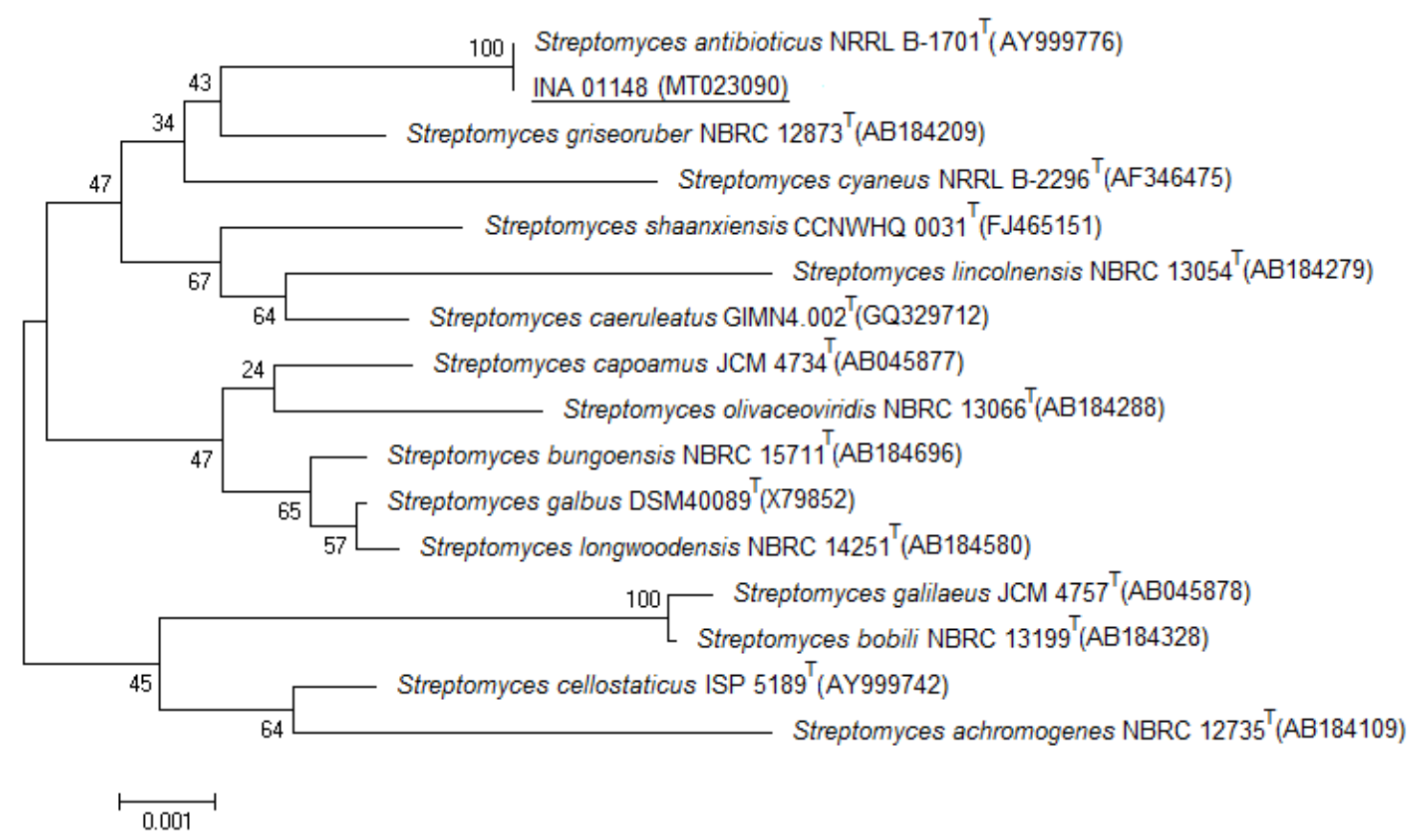

Figure 3. Phylogenetic position of the strain Streptomyces antibioticus-like INA 01148 based on the results of a comparative analysis of the 16S rRNA gene nucleotide sequences. The scale corresponds to one base substitution for every 1000 nucleotides (evolutionary distance). NRRL-Northen Regional Research Center, NBRC-Biological Resource Center, JCM-Japan Collection of Microorganisms, and ISP-International Streptomyces Project.

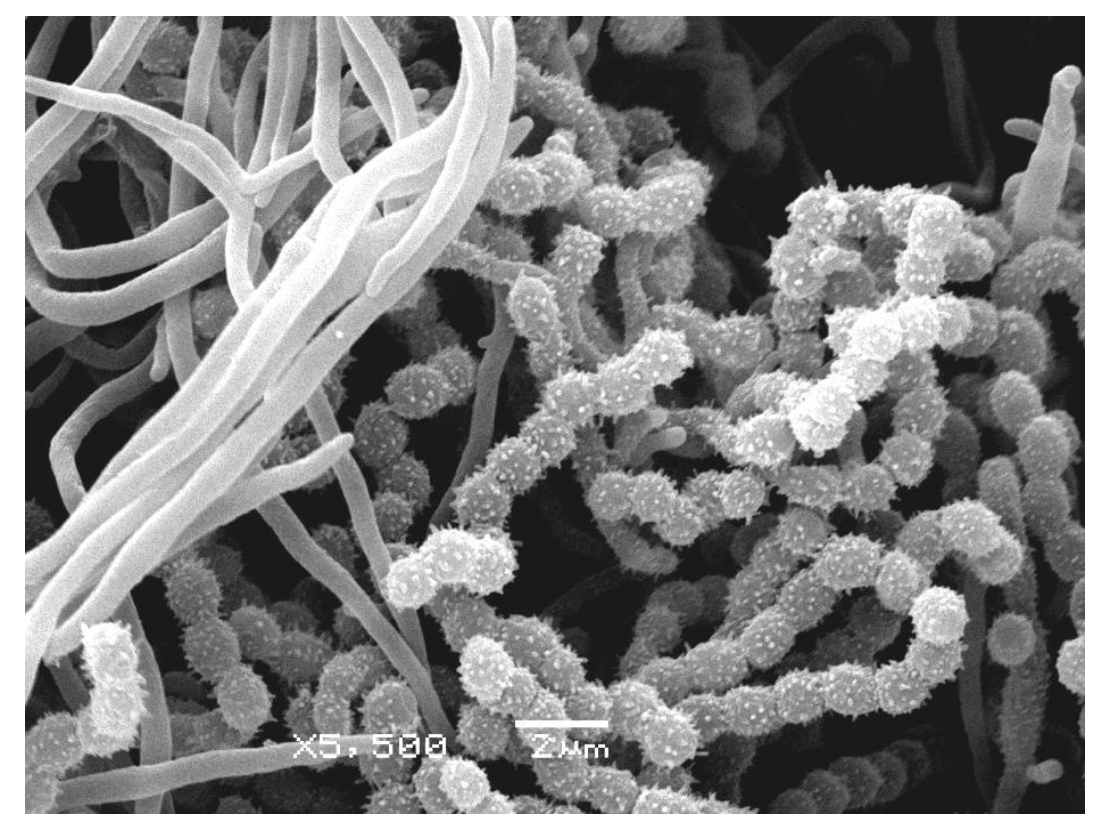

Figure 4. Vegetative mycelium, sporogenous hyphae, and spores of Streptomyces sp. INA 01156 (scanning electron microscopy).

Thus, representatives of four species of the family Bacillaceae and two streptomycetes were isolated from the two nests of ants. 


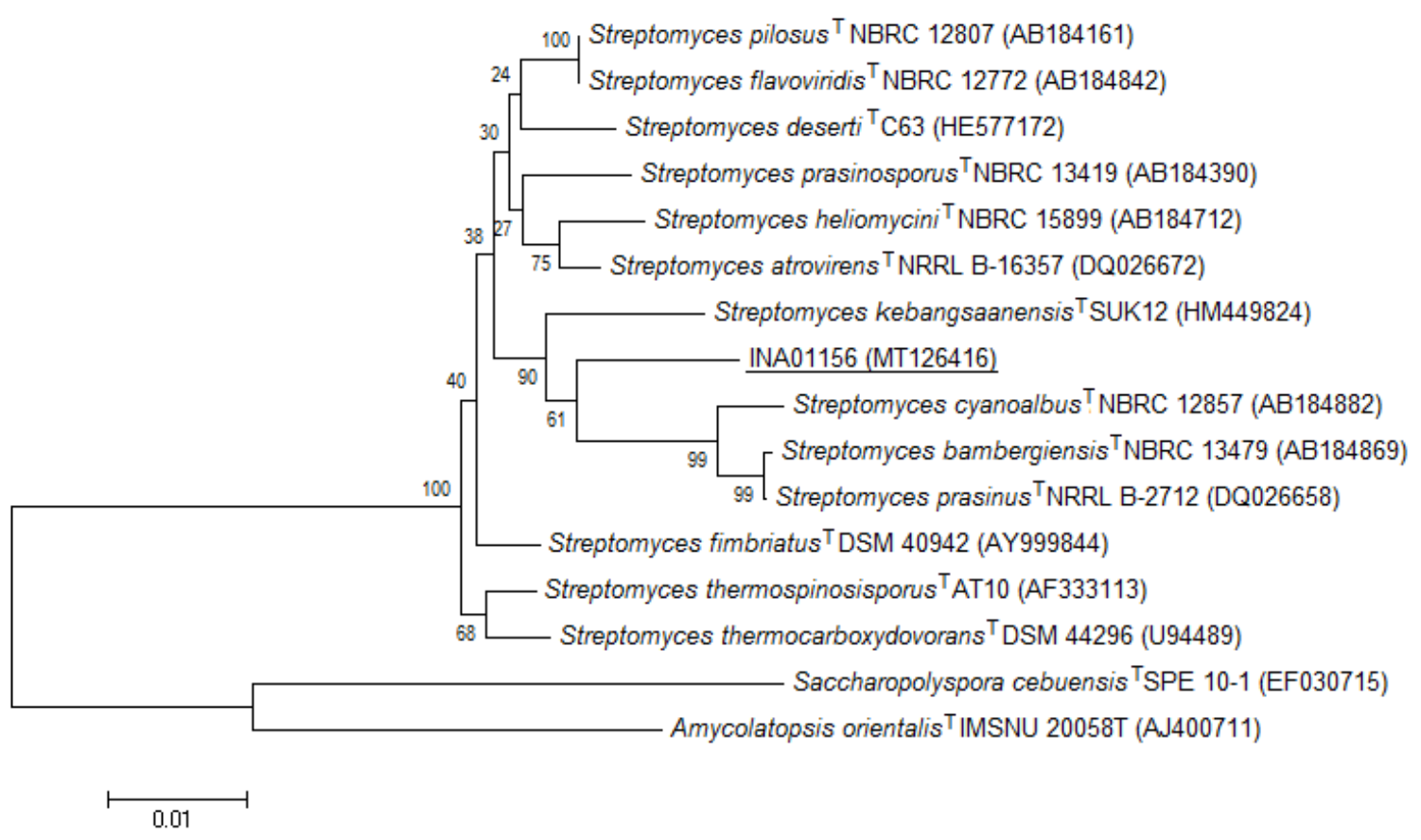

Figure 5. Phylogenetic position of the strain Streptomyces sp. INA 01156 based on the results of comparative analysis of the $16 \mathrm{~S}$ rRNA gene nucleotide sequences. The scale corresponds to two base substitutions for every 1000 nucleotides (evolutionary distance). IMSNU-Institute of Microbiology, Seoul National University.

\subsection{Antimicrobial Activity of the Bacterial Isolates}

The antimicrobial properties of the six strains of four species of bacilli presented in Table 2 were determined. The activity of the whole bacterial broth culture was analyzed against 14 test strains of the microorganisms listed in Section 2. None of the isolated bacilli showed antibiotic activity against Gram-positive or Gram-negative bacteria or activity against fungi.

Four isolates of the S. antibioticus-like bacteria, including strain INA 01148, exhibited antibiotic activity against the Gram-positive bacterial test strains St. aureus FDA 209P, St. aureus INA 00761, B. subtilis ATCC 6633, and M. luteus NCTC 8340, as well as some antifungal activity in four media out of seven; activity against Leuconostoc mesenteroides VKPM B-4177 and E. coli ATCC 25922 was absent. There were no differences in the antimicrobial spectra of the four actinomycete isolates; the diameters of the zones of growth suppression differed insignificantly (Table 3). The effect of the broth of the isolates on each other was tested. Bacillus sp. INA 01161, Bacillus muralis-like INA 01162, and Lysinibacillus pakistanensis-like INA 01164 did not inhibit S. antibioticus-like INA 01148 growth, but S. antibioticus-like INA 01148 inhibited all three bacillary isolates (Table 3).

The antimicrobial activity of the broth of four Streptomyces spp. isolates from ant nest 2 was tested. No activity was detected in the two isolates. In another isolate (No. 4951), the activity of the broth was only found against M. luteus NCTC 8340 on two media out of seven (media A4 and 2663), and zones of growth inhibition were negligible $(12-15 \mathrm{~mm})$. Only one isolate was active in six out of seven culture media, Streptomyces sp. INA 01156 (Table 4). This isolate showed antimicrobial activity directed against Gram-positive bacteria only. Presumably, this strain can produce more than one antibiotic, because, for example, at approximately the same level of activity against B. subtilis ATCC 6633 and M. luteus NCTC 8340 (on media 6613 and 330), it also exhibited activity against St. aureus FDA 209P and Leuc. mesenteroides VKPM B-4177, but only on medium 330 (Table 4). 
Table 3. Antimicrobial activity of the Streptomyces antibioticus-like INA 01148 broth against test strains and bacterial isolates from ant nest 1 (zones of growth inhibition in $\mathrm{mm}$ ).

\begin{tabular}{|c|c|c|c|c|c|c|c|c|c|c|c|}
\hline \multirow[b]{2}{*}{$\begin{array}{c}\text { Culture } \\
\text { Media [26] }\end{array}$} & \multicolumn{8}{|c|}{ Collection Test Strains } & \multicolumn{3}{|c|}{ Bacillary Isolates from Ant Nest 1} \\
\hline & $\begin{array}{l}\text { Staphilococcus } \\
\text { aureus INA } \\
00761\end{array}$ & $\begin{array}{l}\text { St. aureus } \\
\text { FDA 209P }\end{array}$ & $\begin{array}{c}\text { Bacillus } \\
\text { subtilis } \\
\text { ATCC } 6633\end{array}$ & $\begin{array}{l}\text { Micrococcus } \\
\quad \text { luteus } \\
\text { NCTC } 8340\end{array}$ & $\begin{array}{l}\text { Leuconostoc } \\
\text { mesenteroides } \\
\text { VKPM B-4177 }\end{array}$ & $\begin{array}{l}\text { Escherichia } \\
\text { coli ATCC } \\
25922\end{array}$ & $\begin{array}{c}\text { Aspergillus } \\
\text { niger INA } \\
00760\end{array}$ & $\begin{array}{l}\text { Saccharomyces } \\
\text { cerevisiae } \\
\text { RIA } 259\end{array}$ & $\begin{array}{l}\text { Bacillus sp. } \\
\text { INA } 01161\end{array}$ & $\begin{array}{c}B . \\
\text { muralis-like } \\
\text { INA } 01162 \\
\end{array}$ & $\begin{array}{c}\text { Lys. } \\
\text { pakistanensis-like } \\
\text { INA } 01164\end{array}$ \\
\hline 2263 & $24.3 \pm 0.6$ & $23.7 \pm 1.5$ & $23.3 \pm 2.3$ & $22.3 \pm 1.5$ & 0 & 0 & 0 & 0 & $25.3 \pm 2.5$ & $30.7 \pm 3.1$ & $22.3 \pm 3.8$ \\
\hline A4 & $23.3 \pm 5.9$ & $20.7 \pm 4.0$ & $24.0 \pm 6.9$ & $23.0 \pm 6.1$ & 0 & 0 & $14.3 \pm 0.6$ & $19.7 \pm 1.5$ & $26.7 \pm 5.1$ & $33.3 \pm 3.1$ & $29.7 \pm 4.9$ \\
\hline Suc & $27.3 \pm 3.1$ & $25.3 \pm 1.5$ & $27.3 \pm 2.5$ & $24.7 \pm 3.1$ & 0 & 0 & 0 & 0 & $29.3 \pm 3.2$ & $31.7 \pm 1.2$ & $29.7 \pm 0.6$ \\
\hline 5339 & $23.3 \pm 4.7$ & $21.0 \pm 5.3$ & $23.7 \pm 4.2$ & $22.0 \pm 4.0$ & 0 & 0 & 0 & $17.7 \pm 3.1$ & $24.7 \pm 4.5$ & $30.7 \pm 3.5$ & $20.3 \pm 2.5$ \\
\hline 6613 & $26.0 \pm 1.0$ & $24.0 \pm 3.6$ & $26.3 \pm 2.1$ & $23.3 \pm 4.7$ & 0 & 0 & 0 & $13.7 \pm 1.5$ & $30.0 \pm 2.0$ & $30.0 \pm 2.6$ & $32.3 \pm 3.1$ \\
\hline 330 & $27.3 \pm 1.2$ & $24.0 \pm 3.5$ & $26.0 \pm 2.6$ & $25.3 \pm 1.5$ & 0 & 0 & 0 & $13.7 \pm 1.5$ & $24.7 \pm 2.1$ & $32.7 \pm 2.5$ & $32.0 \pm 3.6$ \\
\hline $\mathrm{Am}$ & $25.7 \pm 2.5$ & $22.7 \pm 4.2$ & $24.7 \pm 4.0$ & $24.7 \pm 3.1$ & 0 & 0 & 0 & 0 & $24.7 \pm 2.1$ & $31.3 \pm 3.1$ & $30.3 \pm 1.5$ \\
\hline
\end{tabular}

Table 4. Antimicrobial activity of the Streptomyces sp. INA 01156 broth against test strains and bacterial isolates from ant nest 2 (zones of growth inhibition in mm).

\begin{tabular}{|c|c|c|c|c|c|c|c|c|c|c|c|}
\hline \multirow[b]{2}{*}{$\begin{array}{c}\text { Culture } \\
\text { Media [26] }\end{array}$} & \multicolumn{8}{|c|}{ Collection Test Strains } & \multicolumn{3}{|c|}{ Bacillary Isolates from Ant Nest 2} \\
\hline & $\begin{array}{l}\text { St. aureus } \\
\text { INA } 00761\end{array}$ & $\begin{array}{l}\text { St. aureus } \\
\text { FDA 209P }\end{array}$ & $\begin{array}{c}\text { B. subtilis } \\
\text { ATCC } 6633\end{array}$ & $\begin{array}{l}\text { M. luteus } \\
\text { NCTC } 8340\end{array}$ & $\begin{array}{c}\text { Leuc. } \\
\text { Mesenteroides } \\
\text { VKPM B-4177 }\end{array}$ & $\begin{array}{c}\text { E. coli ATCC } \\
25922\end{array}$ & $\begin{array}{c}\text { A. niger INA } \\
00760\end{array}$ & $\begin{array}{c}\text { Sac. } \\
\text { cerevisiae } \\
\text { RIA } 259\end{array}$ & $\begin{array}{l}\text { Bacillus sp. } \\
\text { INA } 01158\end{array}$ & $\begin{array}{c}B . \\
\text { muralism-like } \\
\text { INA 01160 }\end{array}$ & $\begin{array}{c}B . \\
\text { aryabhattai-like } \\
\text { INA } 01159\end{array}$ \\
\hline 2263 & 0 & 0 & 0 & 0 & 0 & 0 & 0 & 0 & 0 & 0 & 0 \\
\hline $\mathrm{A} 4$ & 0 & 0 & 0 & $17.3 \pm 2.5$ & 0 & 0 & 0 & 0 & $18.7 \pm 3.1$ & $15.3 \pm 3.2$ & $19.7 \pm 2.9$ \\
\hline Suc & 0 & 0 & 0 & $15.7 \pm 3.6$ & 0 & 0 & 0 & 0 & $17.3 \pm 3.0$ & $18.7 \pm 4.2$ & $19.7 \pm 1.1$ \\
\hline 5339 & 0 & 0 & $17.3 \pm 4.0$ & $19.3 \pm 3.1$ & 0 & 0 & 0 & 0 & $20.3 \pm 1.5$ & $20.7 \pm 3.1$ & $21.3 \pm 1.5$ \\
\hline 6613 & 0 & 0 & $21.7 \pm 2.1$ & $21.7 \pm 2.5$ & 0 & 0 & 0 & 0 & $21.0 \pm 2.3$ & $20.0 \pm 2.7$ & $20.3 \pm 3.4$ \\
\hline 330 & 0 & $15.7 \pm 2.5$ & $20.7 \pm 3.5$ & $19.7 \pm 2.1$ & $15.3 \pm 0.6$ & 0 & 0 & 0 & $19.7 \pm 3.1$ & $20.7 \pm 2.6$ & $22.0 \pm 0.6$ \\
\hline $\mathrm{Am}$ & $15.3 \pm 1.5$ & $15.3 \pm 0.6$ & $12.3 \pm 0.6$ & $18.7 \pm 3.5$ & 0 & 0 & 0 & 0 & $16.7 \pm 2.7$ & $17.3 \pm 3.1$ & $20.1 \pm 1.2$ \\
\hline
\end{tabular}


3.3. Isolation and Purification of Antimicrobial Substances from the Streptomyces antibioticus-like INA 01148 Broth

Since all four S. antibioticus-like isolates had the same antimicrobial spectrum of the broth during growth in different nutrient media and the concentrates had the same bright orange colorization, a single strain was taken for chemical analysis (S. antibioticus-like INA 01148). The antibiotic isolated had the following UV spectrum (MeOH): $\lambda_{\max } 217 \mathrm{~nm}$ (2.95 Abs), 237.2 nm (3.26 Abs), $426.6 \mathrm{~nm}$ (1.29 Abs), and $443 \mathrm{~nm}$ (1.30 Abs). According to TLC, the antibiotic had Rf =0.7. Based on the UV spectrum and TLC data, the antibiotic matched the well-known antibiotic actinomycin D (dactinomycin). To confirm this conclusion, we undertook column calibration with the actinomycin D analytical standard (Serva, Catoosa, OK, USA). Three samples of the broth were analyzed by analytical RP-HPLC with absorbance detection at $237 \mathrm{~nm}$ : eluate supernatant concentrate (Figure 6A), mycelium extract concentrate (Figure 6C), combined eluate and supernatant concentrate after preparative TLC purification (Figure 6D), and actinomycin D standard (Figure 6B). As illustrated, all three S. antibioticus-like INA 01148 samples contained a major compound with a retention time of $42.6 \mathrm{~min}$, which is quite close to the standard variant of actinomycin D.

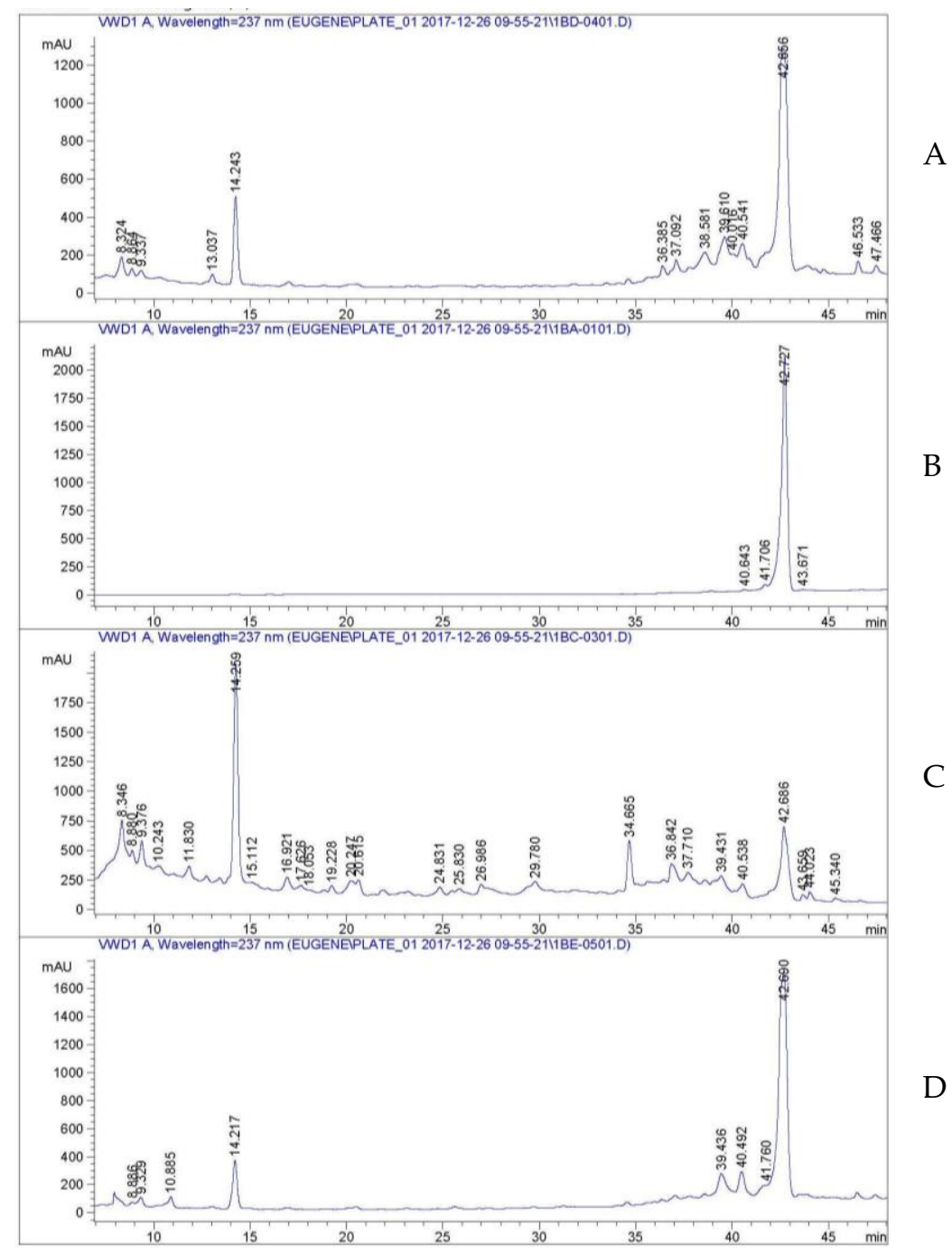

Figure 6. Comparative analytical reversed-phase high performance liquid chromatography (RP-HPLC) analysis of the eluate supernatant concentrate (A), the mycelium extract concentrate (C), and the combined eluate and supernatant concentrate after preparative thin-layer chromatography (TLC) purification (D) against the actinomycin D analytical standard (B). 
For further identification, the combined eluate and supernatant concentrate after preparative TLC purification was analyzed by liquid chromatography-electrospray ionization-mass spectrometry (LC-ESI-MS), and an accuracy $\mathrm{m} / \mathrm{z}$ value of the target compound was measured (Figure 7). As shown in Figure 7, the analyzed compound was represented by two approximately equal components with retention times (RT) of 7.34 and $7.54 \mathrm{~min}$. The measured $\mathrm{m} / \mathrm{z}$ value for the first peak $(\mathrm{RT}=7.34 \mathrm{~min})$ was $1255.6 \mathrm{Da}$, allowing identification of actinomycin $\mathrm{D}$ (calculated $\mathrm{m} / \mathrm{z}$ value $1255.42 \mathrm{Da}$ ). The $\mathrm{m} / \mathrm{z}$ value's second peak ( $\mathrm{RT}=7.54 \mathrm{~min})$ was $1269.47 \mathrm{Da}(+14 \mathrm{Da})$, matching the peak of the highest homologue, actinomycin A1 [33].

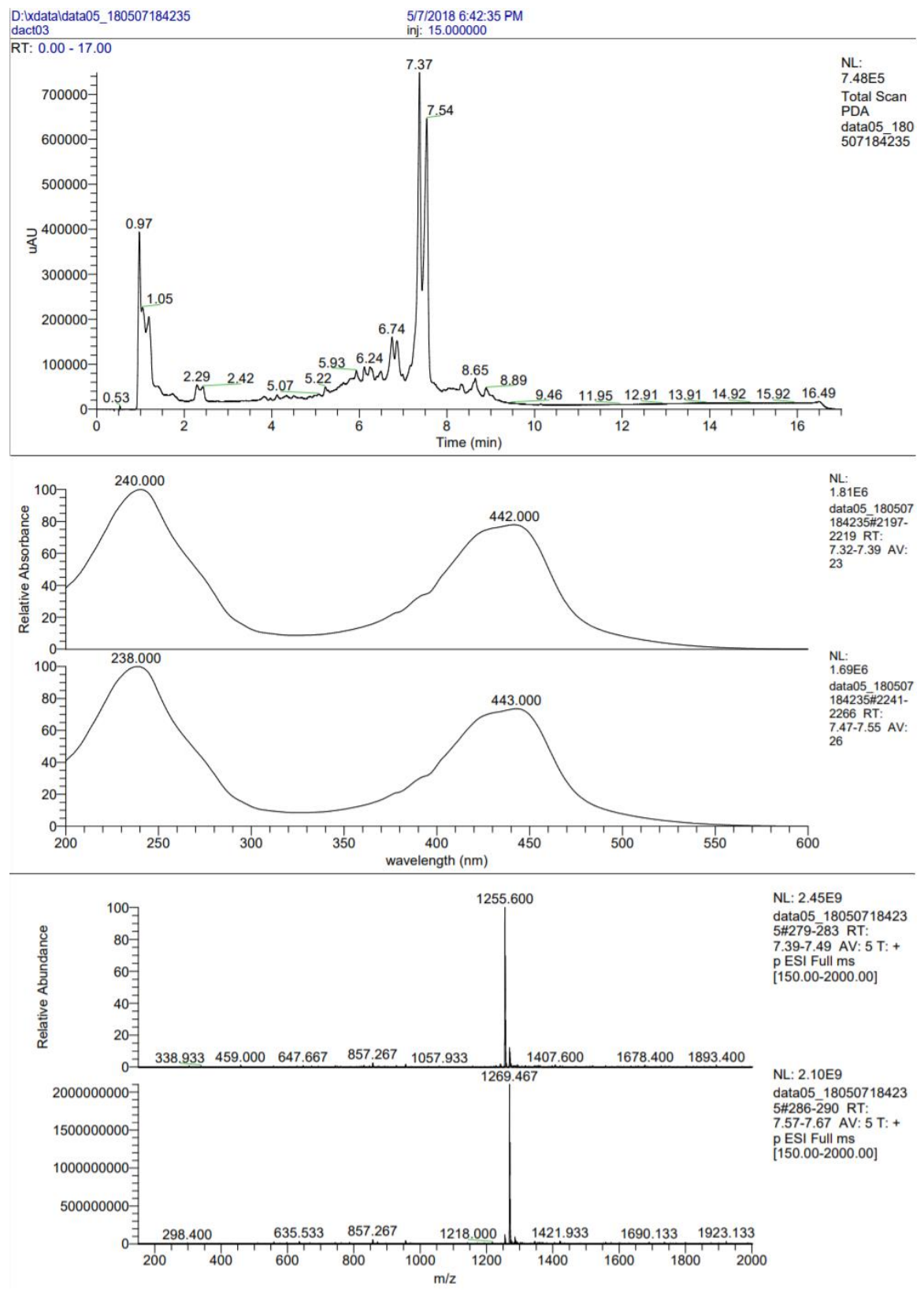

Figure 7. Liquid chromatography-electrospray ionization-mass spectrometry (LC-ESI/MS) analysis of the sample with two actinomycin components after previous preparative thin-layer chromatography (TLC) purification: the top panel shows the profile of the analytical reversed-phase HPLC of the sample (actinomycin D is eluted at 7.37, actinomycin A at $7.54 \mathrm{~min}$, respectively); the middle panel shows the UV spectra of actinomycin D and actinomycin A (top-down); the lower panel shows the ESI/MS spectra of actinomycin D and actinomycin A (top-down). RT-retention time; NL-intensity of the base peak; PDA-type of measurement; AV-mode of measurement (average). 


\subsection{Sensitivity of Bacterial Isolates to the Antibiotic Actinomycin D and the Interactions of These Isolates}

After identifying actinomycin D as the antibiotic produced by the strain S. antibioticus-like INA 01148, we suggested that, in nature, this antibiotic can be produced and affect the growth of other microorganisms present in the substrate of ant nest 1 (Table 3). We found that all three bacilli were sensitive to small doses of actinomycin D (Table 5).

Table 5. Minimum inhibitory concentration (MIC) of actinomycin D for inhibiting the growth of isolates from the substrate of the ant nest 1 strains.

\begin{tabular}{cc}
\hline Microbial Isolates from Ant Nest & MIC of Actinomycin D ( $\mu$ g/disc) \\
\hline Bacillus muralis-like INA 01162 & 0.125 \\
Bacillus sp. INA 01161 & 0.06 \\
Lysinibacillus pakistanensis-like INA 01164 & 0.125 \\
Streptomyces antibioticus-like INA 01148 & $>64^{*}$ \\
\hline
\end{tabular}

* The maximum concentration in the experiment.

To simulate the effects of combined growth of bacteria in a substrate, we sowed four microbial isolates from ant nest 1 on the agar medium next to each other and incubated them at $28^{\circ} \mathrm{C}$. Six pairwise combinations of four different species isolates were examined (Table 2), but inhibition of the growth of any of the microorganisms due to the substances secreted into the agar medium by the neighboring strain was not observed. Since under submerged cultivation only S. antibioticus-like had antimicrobial properties, in the next step, we sowed S. antibioticus-like INA 01148 four days earlier than the three bacilli. With this seeding, the strain S. antibioticus-like INA 01148 inhibited the growth of three species of bacilli: Lys. pakistanensis-like INA 01164, Bacillus sp. INA 01161, and B. muralis-like INA 01162. The last two bacteria are shown in Figure 8.

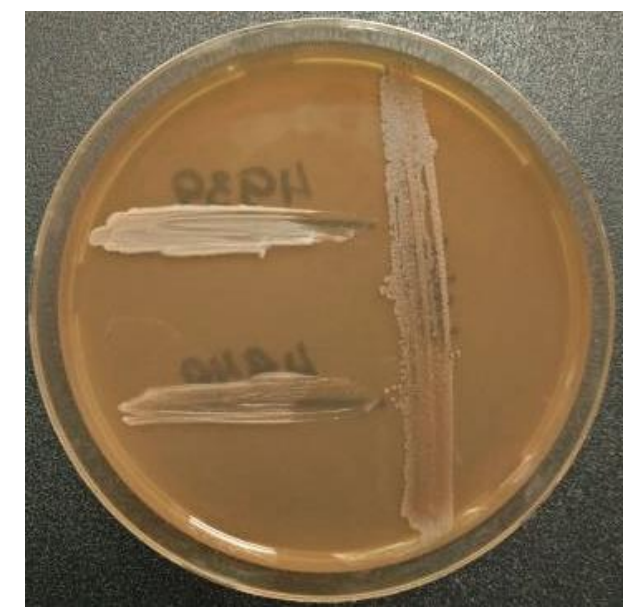

Figure 8. S. antibioticus-like INA 01148 (vertical bar) inhibits the growth of the bacteria Bacillus sp. INA 01161 (top bar) and B. muralis-like INA 01162.

\section{Discussion}

The production of antibiotics by microorganisms can be considered an evolutionarily developed defense mechanism in interspecific competition or a chemical weapon in the struggle for existence. A large number of different antibiotics produced by actinomycetes have been described, along with those produced by representatives of other groups of microorganisms such as bacilli and fungi.

Previous publications by various authors described the isolation of microorganisms from substrates of anthills. For example, the abovementioned fungus-growing ants and antibiotics produced by Pseudonocardia spp. These actinomycetes inhibit the growth of ant mycopathogens, such as Escovopsis spp. [18,19]. 
The symbiotic association between ants and antibiotic-producing microorganisms was previously reported by several different authors [5-10,12-15,19,23]. Various studies of microorganisms accompanying L. niger have been conducted, and fungi (from the genera Penicillium, Acremonium, and Mucor), bacteria of various taxonomic groups, including bacilli, and a large number of actinomycetes (from the genera Streptomyces, Nocardia, and Micromonospora) have been described [23]. The results obtained were unexpected for us, since fungi were completely absent in the cultures of substrates from the nests of ants we studied, and the species composition of the bacteria was poor: Gram-negative bacteria were absent and only four species of Gram-positive bacteria were found in the two nests. In both cases, they were representatives of two species of the genus Bacillus (B. muralis-like and Bacillus sp.), as well as Lysinibacillus pakistanensis-like (nest 1) and B. aryabhattai-like (nest 2); actinomycetes were represented by two species of the Streptomyces genus, one of which was identified as $S$. antibioticus-like (nest 1 ).

This small number of cultivated species cannot be explained by the selected agar medium for cultivation or by cultivation conditions. Traditionally, most species of bacilli, actinomycetes, and soil fungi isolated from the soils of the Moscow Region grow well on Gause agar medium \#2. This medium is also suitable for the growth of microorganisms previously isolated from L. niger anthills [23-25]. Although the nests were located in the same garden in neighboring apple trees, the partial discrepancy in the species composition of bacteria can be explained by the difference in the properties of the substrates inside the nests (Table 1), which could be related to some differences in the trees and could affect the species composition of microbial communities. The concentrations of CFU in the substrates of both nests were approximately equal to each other and also fell into the range of concentrations of CFU found in previous publications on anthills of L. niger [23].

The results differ in terms of the number and diversity of microorganisms compared to those previously described for L. niger. This may be due to microbial communities in the anthills of L. niger located on the ground being more commonly studied. In this publication, we investigated the microbial communities localized in the cavities of old trees. The species composition of microorganisms from anthills varies depending on the time of year, being less diverse in spring than in autumn [23,34]. We took substrate samples from the ant nests in spring, which could have affected the species composition of the microbial community. Golichenkov et al. noted that seasonal changes in the bacterial complex in the domed part of the Lasius niger anthill may be associated with the antibiotic action of actinomycetes. This conclusion was drawn on the basis that, for example, absolute dominance of bacilli was observed in spring, when Streptomyces albus prevailed over actinomycetes, exhibiting a wide range of antibacterial activity against all bacteria isolated from the anthill (Arthrobacter spp., Cellulomonas spp., Flavobacterium-Cytophaga, and Rhodococcus spp.) with the exception of Bacillus spp. [23].

None of the four representatives of the Bacillaceae family showing antimicrobial activity was also unexpected, which, in our experience, is rare. On the contrary, both actinomycetes have antibiotic properties and, in addition to the test strains, also inhibit the growth of own bacteria (Tables 3 and 4). Antibiotics produced by S. antibioticus-like INA 01148 were identified as actinomycin D and its analogue. In high concentrations, actinomycin D also inhibits the growth of fungi, which could explain the absence of fungi in the substrate of nest $1[35,36]$. Bacteria from nest 1 were sensitive to actinomycin D (Table 5), and this antibiotic probably inhibited bacterial growth when co-streaked on the agar medium, provided that the producer of actinomycin D was inoculated earlier and, probably, an antibiotic was already released into the medium (Figure 8). However, if the producer of actinomycin D and the bacilli are inoculated simultaneously, both strains of the bacilli grow and a part of the population forms spores. Under natural conditions in the microworld, bacilli likely also partially diverge with actinomycetes in time and space, which allows bacilli populations to survive. Actinomycin D producers among actinomycetes producing antibiotics are found in the nature at a high frequency-from 1:10 to $1: 1000$. In comparison, the frequency of occurrence in the nature of the producer of daptomycin is $1: 1,000,000$ [37]. This high frequency of occurrence in the nature is probably the reason that actinomycin D was one of the first discovered antibiotics [38]. Previously, actinomycins were isolated from substrates 
of nests, integuments, and feces of leaf-cutting ants of three species. Several antibiotics were discovered in that work, with the authors suggesting that the diversity of natural products plays a driving role in shaping the ecosystems of leaf-cutting ants [18].

Streptomyces sp. INA 01156 exhibited antibiotic properties against Gram-positive bacteria, including three species of bacilli, which were also isolated from ant nest 2 (Table 4). Further investigation of the structure of this antibiotic (or antibiotics) is planned.

The isolates of two populations of actinomycetes differed in the level of antibiotic activity (from zero to high). Such variability in natural actinomycete populations can have adaptive value when environmental conditions change if antibiotic formation is considered protection against competitive microflora.

\section{Conclusions}

The microbial communities of two nests of black garden ants (Lasius niger) in the hollows of stem branches of old apple trees showed similar species compositions: each community contained representatives of three species from the Bacillaceae family and one species of actinomycetes from the genus Streptomyces. Small differences in the species composition of microorganisms were apparently related to the difference in substrates in the nests, mainly in the $\mathrm{pH}$ value (7.81 and 7.22). This could affect the established species composition, although the trees were located at a distance of $5 \mathrm{~m}$ from each other.

None of the bacilli showed antibiotic activity, and both streptomycetes produced antibiotics that inhibited the growth of Gram-positive bacteria in vitro, including those from their community. We determined that one of the actinomycetes, S. antibioticus-like INA 01148, can produce actinomycins, due to the action of which Gram-negative bacterial and fungal microflora were suppressed. The second actinomycete, Streptomyces sp. INA 01156, can produce an antibiotic (or antibiotics) of an unknown nature that inhibits the growth of drug-resistant bacteria, which may be of practical interest.

The difference between these microbial communities and those previously described in L. niger, and represented by a large number of species of actinomycetes, fungi, and bacteria of different taxonomic groups, is probably due to anthills located on the ground and not ant nests being studied.

Author Contributions: A.A.G. and O.V.E. conceived and designed the experiments; T.A.E., A.A.G., M.V.D., Y.V.B., N.D.M., I.G.S., B.F.V., E.A.R., I.A.I., V.A.K., O.V.E. performed the experiments; T.A.E., E.A.R. and O.V.E. analyzed the data; T.A.E., E.A.R. and O.V.E. wrote the paper. All authors have read and agreed to the published version of the manuscript.

Funding: This work was conducted as part of the research program of Gause Institute of New Antibiotics on state assignments, as well as with partial support from the Russian Foundation for Basic Research (RFBR, project 17-00-00393).

Acknowledgments: The authors are grateful to O.V. Kamzolkina from Lomonosov Moscow State University for electron microscopy of the actinomycete spores.

Conflicts of Interest: The authors declare no conflicts of interest.

\section{References}

1. Butler, M.S.; Blaskovich, M.A.; Cooper, M.A. Antibiotics in the clinical pipeline at the end of 2015. J. Antibiot. 2017, 70, 3-24. [CrossRef] [PubMed]

2. Berdy, J. Thoughts and facts about antibiotics: Where we are now and where we are heading. J. Antibiot. 2012, 65, 385-395. [CrossRef] [PubMed]

3. Efimenko, T.A.; Terekhova, L.P.; Efremenkova, O.V. Current State the Problem of Antibiotic Resistance of Pathogens. Antibiot. Khimioterapiya 2019, 64, 64-68. (In Russian)

4. Schultz, T.R. In search of ant ancestors. Proc. Natl. Acad. Sci. USA 2000, 97, 14028-14029. [CrossRef]

5. Schultz, T. Ants, plants and antibiotics. Nature 1999, 398, 747-748. [CrossRef]

6. Currie, C.R. A community of ants, fungi, and bacteria: A multilateral approach to studying symbiosis. Annu. Rev. Microbiol. 2001, 55, 357-380. [CrossRef] 
7. Ishak, H.D.; Miller, J.L.; Sen, R.; Dowd, S.E.; Meyer, E.; Mueller, U.G. Microbiomes of ant castes implicate new microbial roles in the fungus-growing ant Trachymyrmex septentrionalis. Sci. Rep. 2011, 1, 204. [CrossRef]

8. Cafaro, M.J.; Poulsen, M.; Little, A.E.F.; Price, S.L.; Gerardo, N.M.; Wong, B.; Stuart, A.E.; Larget, B.; Abbot, P.; Currie, C.R. Specificity in the Symbiotic Association Between Fungus-Growing Ants and Protective Pseudonocardia Bacteria. Proc. Biol. Sci. 2011, 278, 1814-1822. [CrossRef]

9. Mueller, U.G. Symbiont recruitment versus ant-symbiont co-evolution in the attine ant-microbe symbiosis. Curr. Opin. Microbiol. 2012, 15, 269-277. [CrossRef]

10. Caldera, E.J.; Chevrette, M.G.; McDonald, B.R.; Currie, C.R. Local Adaptation of Bacterial Symbionts within a Geographic Mosaic of Antibiotic Coevolution. Appl. Environ. Microbiol. 2019, 85. [CrossRef]

11. Oh, D.C.; Poulsen, M.; Cameron, R.; Currie, C.R.; Clardy, J. Dentigerumycin: A Bacterial Mediator of an Ant-Fungus Symbiosis. Nat. Chem. Biol. 2009, 5, 391-393. [CrossRef]

12. Newman, D.J.; Cragg, G.M. Endophytic and epiphytic microbes as "sources" of bioactive agents. Front. Chem. 2015, 3, 34. [CrossRef]

13. Sit, C.S.; Ruzzini, A.C.; Van Arnam, E.B.; Ramadhar, T.R.; Currie, C.R.; Jon Clardy, J. Variable Genetic Architectures Produce Virtually Identical Molecules in Bacterial Symbionts of Fungus-Growing Ants. Proc. Natl. Acad. Sci. USA 2015, 112, 13150-13154. [CrossRef] [PubMed]

14. Currie, C.R.; Scott, J.A.; Summerbell, R.C.; Malloch, D. Fungus-growing ants use antibiotic-producing bacteria to control garden parasites. Nature 1999, 398, 701-704. [CrossRef]

15. Sen, R.; Ishak, H.D.; Estrada, D.; Dowd, S.E.; Hong, E.; Mueller, U.G. Generalized antifungal activity and 454-screening of Pseudonocardia and Amycolatopsis bacteria in nests of fungus-growing ants. Proc. Natl. Acad. Sci. USA 2009, 106, 17805-17810. [CrossRef] [PubMed]

16. Kaltenpoth, M. Actinobacteria as mutualists: General healthcare for insects? Trends Microbiol. 2009, 17, 529-535. [CrossRef] [PubMed]

17. Zucchi, T.D.; Guidolin, A.S.; Cônsoli, F.L. Isolation and characterization of actinobacteria ectosymbionts from Acromyrmex subterraneus brunneus (Hymenoptera, Formicidae). Microbiol. Res. 2011, 166, 68-76. [CrossRef]

18. Schoenian, I.; Spiteller, M.; Ghaste, M.; Wirth, R.; Herz, H.; Spiteller, D. Chemical basis of the synergism and antagonism in microbial communities in the nests of leaf-cutting ants. Proc. Natl. Acad. Sci. USA 2011, 108, 1955-1960. [CrossRef]

19. Haeder, S.; Wirth, R.; Herz, H.; Spiteller, D. Candicidin-producing Streptomyces support leaf-cutting ants to protect their fungus garden against the pathogenic fungus Escovopsis. Proc. Natl. Acad. Sci. USA 2009, 106, 4742-4746. [CrossRef]

20. Arnoldi, K.V.; Dlussky, G.M. Key to Insects of the European Part of the USSR; Science: Leningrad, Russia, 1978; Volume I, pp. 519-556.

21. Kupyanskaya, A.N. Key to Insects of the Far East of Russia; Science: St. Petersburg, Russia, 1995; Volume IV, pp. 325-368. (In Russian)

22. Novgorodova, T.A. Organization of honeydew collection by foragers of different species of ants (Hymenoptera: Formicidae): Effect of colony size and species specificity. Eur. J. Entomol. 2015, 112, 688-697. [CrossRef]

23. Golichenkov, M.V.; Novoselov, A.L.; Marfenina, O.E.; Dobrovol'skaya, T.G.; Zakalyukina, Y.V.; Lapygina, E.V.; Zamolodchikov, D.G. Microbiological characteristic of anthills of Lasius niger. Biol. Bull. 2011, 38, $277-282$. [CrossRef]

24. Zakalyukina, Y.V.; Golichenkov, M.V.; Brovkina, O.I.; Putyatina, T.S. Comparative study of actinomycete communities associated with Lasius niger and Formica cunicularia ants and their nests. Moscow Univ. Biol. Sci. Bull. 2014, 69, 118-124. [CrossRef]

25. Zakalyukina, Y.V.; Biryukov, M.V.; Golichenkov, M.V.; Netrusov, A.I. Phenotypic and Phylogenetic Characterization of Actinomycetes Isolated from Lasius niger and Formica cunicularia Ants. Moscow Univ. Biol. Sci. Bull. Microbiol. 2017, 72, 13-19. [CrossRef]

26. Glukhova, A.A.; Karabanova, A.A.; Yakushev, A.V.; Semenyuk, I.I.; Boykova, Y.V.; Malkina, N.D.; Efimenko, T.A.; Ivankova, T.D.; Terekhova, L.P.; Efremenkova, O.V. Antibiotic Activity of Actinobacteria from Digestive Tract of Millipede Nedyopus dawydoffiae (Diplopoda). Antibiotics 2018, 7, 94. [CrossRef] [PubMed]

27. Gause, G.F.; Preobrazhenskaya, T.P.; Sveshnikova, M.A.; Terekhova, L.P.; Maksimova, T.S. The Guide for Identification of Actinomycetes; Nauka: Moscow, Russia, 1983. (In Russian)

28. Shirling, E.B.; Gottlieb, D. Methods for Characterization of Streptomyces Species. IJSB 1966, 16, 317-327. [CrossRef] 
29. Lane, D.J. 16S/23S rRNA sequencing. In Nucleic Acids Techniques in Bacterial Systematics; Stackebrandt, E., Goodfellow, M., Eds.; John Wiley \& Sons: Chichester, UK, 1991; pp. 115-147.

30. Kumar, S.; Stecher, G.; Tamura, K. MEGA7: Molecular Evolutionary Genetics Analysis Version 7.0 for Bigger Datasets. Mol. Biol. Evol. 2016, 33, 1870-1874. [CrossRef]

31. Valagurova, E.V.; Kozyritskaya, V.E.; Iutinskaya, G.A. Actinomycetes of Streptomyces Genus; Naukova dumka: Kyiv, Ukraine, 2003; pp. 180-181. (In Russian)

32. Goodfellow, M.; Kämpfer, P.; Busse, H.J.; Trujillo, M.E.; Suzuki, K.; Ludwig, W.; Whitman, W.B. Bergey's Manual of Systematic Bacteriology, 2nd ed.; Volume 5: The Actinobacteria, Part A; Springer: Athens, GA, USA, 2012; p. 1617.

33. Zhang, X.; Ye, X.; Chai, W.; Lian, X.Y.; Zhang, Z. New Metabolites and Bioactive Actinomycins from Marine-Derived Streptomyces sp. ZZ338. Mar. Drugs 2016, 14, 181. [CrossRef]

34. Dauber, J.; Wolters, V. Microbial activity and functional diversity in the mounds of three different ant species. Soil Biol. Biochem. 2000, 32, 93-99. [CrossRef]

35. Chandrakar, S.; Gupta, A.K. Actinomycin-Producing Endophytic Streptomyces parvulus Associated with Root of Aloe vera and Optimization of Conditions for Antibiotic Production. Probiotics Antimicro. Prot. 2019, 11, 1055-1069. [CrossRef]

36. Kulkarni, M.; Gorthi, S.; Banerjee, G.; Chattopadhyay, P. Production, characterization and optimization of actinomycin D from Streptomyces hydrogenans IB310 (an antagonistic bacterium against phytopathogens). Biocatal. Agric. Biotechnol. 2017, 10, 69-74. [CrossRef]

37. Baltz, R.H. Marcel Faber Roundtable: Is our antibiotic pipeline unproductive because of starvation, constipation or lack of inspiration? J. Ind. Microbial. Biotechnol. 2006, 33, 507-513. [CrossRef] [PubMed]

38. Waksman, S.A.; Tishler, M. The chemical nature of actinomycin, an antimicrobial substance produced by Actinomyces antibioticus. J. Biol. Chem. 1942, 142, 519-528.

(C) 2020 by the authors. Licensee MDPI, Basel, Switzerland. This article is an open access article distributed under the terms and conditions of the Creative Commons Attribution (CC BY) license (http://creativecommons.org/licenses/by/4.0/). 